\title{
Student Social Conflicts with Teacher and Its Handling on Guidance and Counseling
}

\author{
Aldi Ihsandi, Amirah Diniaty ${ }^{1}$ \\ ${ }^{1}$ Universitas Islam Negeri Sultan Syarif Kasim Riau
}

\begin{tabular}{l}
\hline Article Info \\
\hline Article history: \\
Received Feb 6 $6^{\text {th }}, 2020$ \\
Revised Feb $7^{\text {th }}, 2020$ \\
Accepted Feb $10^{\text {th }}, 2020$ \\
\hline
\end{tabular}

Keyword:

Case Study, Student Social Conflicts with Teacher, Handling on Guidance and Counseling

\begin{abstract}
Qualitative approach was used in this research and it was in the term of the type of data. The qualitative approach type was a research producing qualitative descriptive data, an approach produced data in the forms of written or spoken words of people and behaviors that could be observed. This research aimed at knowing the causes of student social conflicts with teachers at State Junior High School 1 Bandar Laksamana, Bengkalis Regency, Riau and its handling by a Guidance and Counseling teacher. The subjects of this research were the students, and the objects were student social conflicts with teachers and its handling on Guidance and at State Junior High School 1 Bandar Laksamana, Bengkalis Regency, Riau. The main informants were 9 persons. The informants were 4 students having social conflicts with teachers, 4 teachers having social conflicts with students, and a Guidance and Counseling teacher. Interview and documentation were the techniques of collecting the data. The research findings showed that the causes of student social conflicts with teachers at State Junior High School 1 Bandar Laksamana, Bengkalis Regency, Riau were (1) communication, (2) coming late to the class, (3) not doing the assignment, (4) truanting or not joining the learning, (5) smoking, and (6) dissent. Its handling by a Guidance and Counseling teacher was (1) giving advice, (2) giving punishment, (3) giving a service in Guidance and Counseling, (4) the role of parents, and (5) the handling by the headmaster.
\end{abstract}

(C) 2020 The Authors. Published by UIN Sultan Syarif Kasim Riau.

This is an open access article under the CC BY license

(https://creativecommons.org/licenses/by/4.0)

Corresponding Author:

Aldi Ihsandi

Universitas Islam Negeri Sultan Syarif Kasim Riau

Email: Aldiihsandi40@gmail.com

\section{Pendahuluan}

Konflik sosial yang terjadi di Indonesia setiap tahunnya mengalami peningkatan. Berdasarkan data Kementerian Dalam Negeri selama tahun 2012 jumlah konflik sosial mencapai 89 kasus, padahal pada tahun sebelumnya jumlah 77 kasus. Kasus konflik sosial bagaikan fenomena gunung es, yang terlihat hanya tataran permukaannya saja. Padahal bisa dipastikan jumlah kasus sebenarnya jauh lebih tinggi dari itu. Predikat bangsa Indonesia sebagai bangsa yang memiliki citra ramah tamah sopan santun tampaknya sudah tergerus oleh prilaku bangsanya sendiri. Bagaimana tidak, bentrokan antar warga, bentrokan antar mahasiswa, bentrokan mahasiswa dengan aparat sudah menjadi hal lumrah yang menghiasi pemberitaan di media masa. Bahkan kasus konflik sosial tersebut sampai menelan 
korban jiwa mencapai 28 korban jiwa dan 200 korban luka serius serta kerugian material dan non meterial. (Abdul Ghofar, 2014)

Konflik adalah ketidaksepahaman antara dua atau lebih individu atau kelompok sebagai akibat dari usaha kelompok lainnya yang mengganggu pencapaian tujuan. Dengan kata lain konflik timbul karena suatu pihak mencoba untuk menghalangi atau menggangu pihak lain dalam usahanya mencapai suatu tujuan. (Prahesti Khasanah, 2014) Konflik sosial dapat terjadi antara siswa dengan gurunya di sekolah, ini menunjukkan adanya persoalan moralitas yang cukup serius.

Mudahnya terjadi konflik antara siswa dengan guru di sebabkan oleh kondisi yang belum stabil pada siswa dalam proses perkembangan yaitu berkembang ke arah kematangan atau kemandirian. Untuk mencapai kematangan, siswa memerlukan bimbingan karena mereka masih kurang memiliki pemahaman atau wawasan tentang diri, lingkungan dan pengalaman dalam menentukan arah kehidupannya. Dalam proses perkembangan tersebut, siswa tidak lepas dari konflik atau pertentangan termasuk dengan gurunya sering terjadi konflik di sekolah. (Prahesti Khasanah, 2014)

Salah satu indikasi adanya konflik sosial siswa dengan guru dikarenakan ada bentuk tindak kekerasan yang dilakukan pada siswa oleh guru. Di Indonesia angka kekerasan terhadap siswa secara umum semakin meningkat. Lembaga Perlindungan Anak (LPA) di Jawa Tengah melaporkan sepanjang Januari-Nopember 2003 terdapat 285 kasus kekerasan dan eksploitasi atas siswa, seseorang diantarannya meninggal. Di Sulawesi Selatan pada priode yang sama tercatat 187 kekerasan terhadap siswa, $37 \%$ diantaranya berupa kekerasan seksual dan $19 \%$ kekerasan fisik.

Kasus kekerasan di sekolah juga telah banyak diliputi media massa. Seorang guru olahraga SMP di Surabaya menghukum seorang siswa yang terlambat datang kesekolah dengan berlari beberapa kali putaran. Namun karna fisiknya lemah, sang siswa akirnya meninggal dunia (Muis,2011).

Guru seharusnya tidak melakukan kekerasan fisik terhadap siswa di sekolah. Dalam UndangUndang mendefinisikan bahwa guru adalah pendidik profesional dengan tugas utama mendidik, mengajar, membimbing, mengarahkan, melatih, menilai dan mengevaluasi peserta didik pada pendidikan anak usia dini jalur pendidikan formal, pendidikan dasar dan pendidikan menengah. (M. Shabir U, 2015)

Adapun permasalahan yang dialami oleh siswa dengan guru yaitu adanya siswa yang berbeda pendapat dengan guru atau pelatih, adanya guru yang menekan siswa dikarenakan keterlambatan mengumpulkan tugas, adanya siswa yang berbeda pendapat dengan guru bidang kesiswaaan yang mengenai siswa yang cabut, merorok di jam pelajaran disekolah dan konflik lainnya.

Untuk menangani masalah konflik sosial siswa dengan guru hal ini tentu menjadi tugas pokok seorang guru BK, karena peran seorang guru BK sangat diharapkan mengentaskan permasalahan yang ada. Dalam penanganan masalah konflik sosial guru dengan siswa guru BK dalam meyelesaikan masalah tersebut melalui layanan mediasi. Layanan mediasi merupakan layanan yang dilaksanakan konselor terhadap dua pihak atau lebih yang tidak dalam ketidakcocokan. (Endang Ertanti Suhesti, 2012)

Guru bimbingan konseling tidak bisa melakukan layanan BK tanpa adanya suatu organisasi dan kerja sama pihak-pihak yang berkaitan yaitu kepala sekolah, wakil kepala sekolah, guru mata pelajaran dan staf sekolah lainnya dan mereka semua juga secara bersama menjalin hubungan kerja sama dan bertanggung jawab terhadap pelaksanaan layanan bimbingan dan konseling. Dengan bekerja sama kepada petugas lain dalam melaksanakan tugas-tugasnya maka BK menjadi BK pola yang jelas. Sehingga tidak ada lagi dirasakan seolah-olah guru pembimbing adalah berperan sebagai polisi sekolah atau jaksa sekolah.

Sekolah Menengah Pertama Negeri 1 Bandar Laksamana Kabupaten Bengkalis memiliki satu orang guru bimbingan konseling yang menangani siswa sebanyak 248 siswa terdiri dari kelas 7 berjumlah 69 siswa, kelas 8 berjumlah 84 siswa dan kelas 9 sebanyak 93 siswa. Dengan layanan bimbingan konseling yang sudah diberikan kepada siswa, guru BK akan dapat membantu sekolah untuk mencapai tujuan pendidikan yang dapat menjadikan siswa berkembang secara optimal baik keperibadian, sosial, kognitif, intelektual dan emosional.

Berdasarkan pengamatan dan wawancara yang penulis lakukan di sekolah Menengah Pertama Negeri 1 Bandar Laksamana Kabupaten Bengkalis pada tanggal 03 Mei 2018 ditemukan gejala-gejala ada guru mata pelajaran mengancam siswa di sekolah sehingga siswa takut bahkan dendam pada 
guru tersebut, terjadinya perbedaan pendapat antara siswa dan guru mata pelajaran sehingga muncul emosi kedua belah pihak, ada guru mata pelajaran yang dianggap tidak adil, ada siswa yang tidak mau berkomunikasi dengan guru mata pelajaran, ada persepsi yang salah dalam menilai hukuman yang diberikan guru mata pelajaran.

\section{Metode}

Dalam melakukan Penelitian ini penulis menggunakan metode Wawancara dan Dokumentasi. Wawancara ialah Penulis mengadakan tanya jawab secara langsung kepada guru, guru bimbingan konseling, dan siswa untuk mengetahui pelaksanaan layanan mediasi untuk mengatasi konflik sosial siswa dengan guru. Sedangkan Dokumentasi bisa berbentuk tulisan, gambar, atau karya-karya monumental dari seseorang. Teknik ini penulis gunakan untuk memperoleh data tentang keadaan lokasi sekolah penelitian, seperti keadaan guru, siswa dan penulis mempelajari dokumen yang ada baik berupa buku maupun catatan yang lain.

\section{Hasil dan Pembahasan}

Dalam penilitan ini masih banyak guru yang belum melakukan konseling siswa dikarenakan kendala adanya kesulitan siswa dalam berterusterang untuk menyelesaikan masalah dan pihak orang tua yang tidak mau terlibat langsung dalam proses penanganan kasus siswa. Diterangkan sebagai berikut:

"Hasil layanan biasanya belum sampai 100\% karena kendala-kendala yang telah saya jelaskan sebelumnya yaitu adanya kesulitan siswa dalam berterusterang untuk menyelesaikan masalah dan pihak orang tua yang tidak mau terlibat langsung dari proses penanganan kasus siswa."

Setelah penulis mengumpulkan data yang diperlukan untuk penelitian ini, maka langkah selanjutnya adalah menganalisis data yang diperoleh, untuk data wawancara dianalisa dengan cara kualitatif yaitu kalimat-kalimat. Sedangkan dokumentasi yaitu data mengenai hal-hal yang berupa catatatn, transkip, buku, dan data tentang sekolah.

Jenis Konflik Sosial Siswa denga Guru di Sekolah Menengah Pertama Negeri 1 Bandar Laksamana Kabupaten Bengkalis RiauJenis konflik sosial siswa denga guru di SMPN 1 Bandar Laksamana Kabupaten Bengkalis Riau, Konflik Interpersonal merupakan pertentangan antar seseorang dengan orang lain karna pertentangan kepentingan atau keinginan. Hal ini sering terjadi antar dua orang yang berbeda status, jabatan, bidang kerja dan lain-lain. Adapun konflik sosial yang terjadi antara siswa dengan guru adalah karena perbedaan pandangan, sehingga menyebabkan siswa melanggar peraturan yang berlaku di sekolah.Penyebab Konflik Sosial Siswa denga Guru di Sekolah Menengah Pertama Negeri 1 Bandar Laksamana Kabupaten Bengkalis Riau

Berdasarkan penyajian data di atas, maka hasil analisis penulis KomunikasiKurangnya kemampuan memahami problematika yang timbul dari efek pesan yang sering bias dan tidak utuh, karena keterbatasan yang ada menimbulkan miskomunikasi, misinterpretasi, dan misunderstanding yang sulit dikendalikan menyebabkan terjadinya konflik. Kurangnya kemampuan mengomunikasikan penyebab konflik dapat menimbulkan berbagai tekanan dalam berbagai sektor kehidupan. (M. Ali Syamsuddin Amin, 2017)

Siswa A menyampaikan dalam hal berkomunikasi dengan guru terkadang siswa tidak tepat menggunakan bahasa yang baik dan benar. Penggunaan bahasa atau bicara dengan tidak sopan kepada guru akan menyebabkan suatu konflik sosial antara siswa dan guru.

Terlambat Masuk KelasDampak dari siswa terlambat masuk kelas adalah adanya tingkah laku menyimpang yang menyalahi aturan/tata tertib yang ada di sekolah baik tertulis maupun tidak tertulis. Disamping itu juga akan merugikan siswa, karena akan tertinggal pelajarannya pada jam pertama di sekolah. (Nur Chasanah 2019)

Keterlambatan dalam masuk kelas akan menyebabkan konflik sosial antara siswa dan guru. Siswa D sering terlambat masuk kelas, sehingga menyebabkan suasana belajar terganggu. 
Tidak Mengerjakan TugasKeterampilan menyelesaikan tugas merupakan bagian dari proses pembelajaran, tujuan utamanya adalah membelajarkan siswa. Melalui tugas-tugas itu siswa dituntut untuk mengerjakannya dengan mencari bahan, mempelajari dan mengkaji lebih lanjut. Mengerjakan tugas- tugas tertentu dapat memperoleh pemahaman dan keterampilan baru sesuai dengan materi tugas. Namun bagi siswa yang tidak mengerjakan tugas-tugasnya menyebabkan penilaian dalam pembelajaran tidak lengkap dan banyak hasil belajarnya tidak tuntas. (Suryadi, dkk, 2016)

Siswa B menyatakan bahwa siswa yang tidak menyelesaikan tanggung jawab yang telah diberikan yaitu mengerjakan tugas rumah, menimbulkan konflik sosial anatara siswa dengan guru. Hal ini berarti siswa tidak melaksanakan tugas dan tanggung jawab.

Bermain dalam Proses Belajarialah peristiwa hidup yang sangat digemari oleh anak-anak, melalui kegiatan bermain, dalam kegiatan tersebut terdapat kejiwaan dan kepribadian yang dapat dikembangkan. Hal ini disebabkan karena di dalam aktivitas bermain banyak kejadian-kejadian yang melibatkan keaktifan kejiwaan dan kepribadian pesertanya. Dengan bermain anak dapat mengaktualisasikan seluruh aspek kehidupan yang ingin disampaikannya. Namun jika bermain di saat pembelajaran dapat menganggu proses belajar mengajar yang menyebabkan siswa-siswa tidak konsentrasi dalam pelajaran. (Nurhayati Simatupang, 2005)

Dari siswa B dan siswa C menyatakan bahwa bermain dalam proses belajar di kelas mengakibatkan konflik sosial antara siswa dan guru. Bermain dalam proses belajar akan menyebabkan keributan sehingga membuat proses dua keinginan dalam satu waktu adalah belajar sambil bermain di dalam kelas akan tetapi guru marah kepada saya karena menyebabkan kelas ribut dan suasana belajar tidak efektif lagi," dan "Pertentangan yang pernah terjadi dengan guru adalah dihukum karena tidak mengikuti pembelajaran dengan baik."

Bolos atau Tidak Mengikuti PembelajaranMembolos adalah pergi meninggalkan sekolah tanpa alasan yang tepat pada jam pelajaran dan tidak ijin terlebih dahulu kepada pihak sekolah. Siswa B menyatakan bahwa tidak mengikuti pelajaran menyebabkan konflik sosial siswa dan guru. Hal ini dikarenakan siswa telah melangar peraturan untuk seharusnya mengikuti proses belajar mengajar yang berlangsung.

Kebiasaan merokok dianggap dapat memberikan kenikmatan bagi perokok. Timbulnya rasa kepercayaan diri yang tinggi pada pelajar dan lebih meningkatkan konsentrasi dalam menghadapi masalah. Aspek psikologis turut berkontribusi dalam pola merokok di kalangan remaja. Menjadi perokok atau menjadi kecanduan merokok, merupakan proses dari berbagai tahap inisiasi dan adaptasi. Faktor pemungkin perilaku merokok berupa ketersediaan rokok di lingkungan sekolah siswa dan keterjangkauan uang saku siswa terhadap rokok. Merokok dapat menyebabkan berbagai macam penyakit, baik langsung oleh faktor merokok atau penyakit yang sudah ada sebelumnya dan diperburuk oleh merokok. (Sulastridkk, 2018)

Siswa C dan siswa B menyampaikan merokok menyebabkan konflik sosial siswa dengan guru. Merokok memang seharusnya tidak boleh dilakukan oleh pelajar, hal tersebut telah melanggar peraturan.

Perbedaan pendapat merupakan sebuah filsafat non-persetujuan atau perlawanan terhadap gagasan atau entitas. Antonim istilah tersebut meliputi perjanjian, konsensus dan perhatian, saat satu pendapat menyepakati sebuah proposisi yang dibuat oleh pendapat lain.

Semua siswa menyatakan bahwa perbedaan pendapat menyebabkan konflik sosial anatara siswa dan guru. Perbedaan pendapat di sini mengacu kepada keinginan siswa yang tidak terpenuhi ataupun karena berbeda pandangan mengenai pembelajaran.

Penanganan Guru Bimbingan Konseling terhadap Konflik Sosial Siswa dengan Guru di Sekolah Menengah Pertama Negeri 1 Bandar Laksamana Kabupaten Bengkalis RiauBerdasarkan penyajian data di atas, maka analisis penulis sebagai berikut: 
Pemberian nasihat, proses pembelajaran tidak akan terlepas dari pera guru dalam menyampaikan materi belajar tentunya tidak semudah membalikkan telapak tangan, karena tidak cukup dengan berbicara untuk menyampaikan Materi Belajar kepada para siswa tetapi, harus disertai dengan memberikan contoh juga. Pemberian Materi Belajar dilakukan dalam menyelesaikan masalah secara ringan. (Nunu Nurfirdaus dan Nursiti Hodijah,2018)

Untuk penangan yang paling awal adalah memberi nasihat, nasihat diberikan kepada siswa yang mengalami konflik sosial dengan guru. Guru bimbingan konseling dan guru lainnya menyatakan bahwa nasihat adalah penjelasan kepada siswa mengenai kesalahan yang dilakukannya agar kesalahan tersebut tidak diulang kembali di lain waktu.

Pemberian hukuman di sekolah merupakan pembentukan sikap dan perilaku siswa di sekolah agar patuh dan taat terhadap semua aturan atau kaedah/norma hukum yang ada. (Minal Ardi, 2012)

Untuk menyelesaikan konflik sosial siswa dan guru, keempat guru berpendapat bahwa pemberian hukuman kepada siswa adalah salah satu penanganannya. Dalam pemberian hukuman akan mengakibatkan efek jera dan takut untuk tidak mengulangi kesalahan lagi. Pemberian hukuman di sini, yaitu pemberian nilai di bawah KKM, membersihkan kamar mandi, membersihkan kelas, mencubit, menjewer, dan menarik rambut.

Guru bimbingan konseling menyampaikan bahwa pemberian layanan dalam bimbingan konseling merupakan penanganan yang dapat diberikan kepada siswa untuk menyelesaikan konflik sosial siswa dan guru. Pemilihan pemberian layanan dalam bimbingan konseling harus disesuaikan masalah atau kasus yang terjadi. Adapun layanan yang diberikan ada sembilan, yaitu:Layanan orientasi, yaitu layanan pengenalan lingkungan sekolah, Layanan informasi, yaitu layanan yang memberikan informasi kepada siswa mengenai hal-hal penting bagi siswa, Layanan penempatan dan penyaluran, yaitu layanan untuk menempatkan minat dan bakat yang dimiliki siswa, Layanan penguasaan konten, yaitu layanan dalam memfasilitasi bidang belajar, Layanan konseling individual, yaitu wawancara langsung dengan siswa yang bersangkutan, Layanan bimbingan kelompok, yaitu layanan bimbingan yang diberikan secara berkelompok, Layanan konseling kelompok, yaitu kegiatan yang bersifat penyembuhan kepada siswa yang memiliki kasus yang sama, Layanan mediasi, yaitu meminta pihak lain sebagai mediator tentang permasalahan yang dihadapi, Layanan konsultasi, yaitu peran orang tua untuk ikut untuk sama-sama mencari solusi tentang permasalahan siswa..

Guru bimbingan konseling berpendapat bahwa peran orang tua merupakan penanganan dalam penyelesaian konflik sosial antara siswa dengan guru. Pengaruh orang tua sangat membantu dalam penangan konflik sosial antara siswa dan guru karena orang tua itu mempunyai peranan penting dalam penanganan konflik siswa dan peranan orang tua dapat membina secara langsung konflik yang terjadi.

Peranan pemimpin dalam hal ini kepala sekolah adalah mempengaruhi dan mengarahkan serta memotivasi semua personel sekolah untuk mencapai tujuan pendidikan. Makna dari pernyataan tersebut berarti berhasil tidaknya pelaksanaan bimbingan dan konseling sangat dipengaruhi oleh kepemimpinan kepala sekolah.

Guru bimbingan konseling dan guru B berpendapat bahwa penanganan yang sangat terakhir dilakukan oleh kepala sekolah. Jika guru bimbingan konseling sudah tidak mampu menyelesaikan konflik sosial antara siswa dengan guru, maka jalan terakhir kepala sekolah turun tangan untuk menyelesaikan kasus yang terjadi sampai selesai.

\section{Kesimpulan}


Berdasarkan pemamparan diatas maka dapat disimpulkan bahwa siswa di SMPN 1 Bandar Laksamana Kabupaten Bengkalis Riaukonflik siswa dengan guru dan penanganan dalam bimbingan konseling di SMPN 1 Bandar Laksamana Bengkalis Riau. Teknik pengumpulan data yaitu wawancara dan dokumentasi. Hasil penelitian menunjukkan bahwa Penyebab konflik sosial siswa denga guru di SMPN 1 Bandar Laksamana Kabupaten Bengkalis Riau, yaitu: komunikasi, terlambat masuk kelas, tidak mengerjakan tugas, bolos atau tidak mengikuti pembelajaran, merokok, dan perbedaan pendapat. Adapun Penanganan guru bimbingan konseling terhadap konflik sosial siswa dengan guru di SMPN 1 Bandar Laksamana Kabupaten Bengkalis Riau, yaitu pemberian nasihat, pemberian hukuman, pemberian layanan dalam bimbingan konseling, Peran Orang Tua, dan penanganan dari kepala sekolah.Penanganan guru bimbingan konseling terhadap konflik sosial siswa dengan guru di SMPN 1 Bandar Laksamana Kabupaten Bengkalis Riau, Pemberian nasihat yang dilakukan oleh guru BK, Pemberian hukuman oleh guru mata pelajaran dan guru BK, Pemberian layanan dalam bimbingan konseling, Memanggil orang tua siswa bagi siswa yang mengalami konflik sosial dengan guru, Penanganan dari kepala sekolah yaitu setelah guru BK tidak mampu menangani konflik.

\section{Ucapan Terima Kasih}

Terimakasih di ucapkan kepada kedua orangtua yang telah mesnsuport saya dalam penyelesaian jurnal ini, tak lupa jugak kepada Ibuk Amirah Diniati Selaku Dosen Pembimbing. Sekian terimakasih

\section{Daftar Pustaka}

Abdul Ghofar, 2014,"Antisipasi Potensi Konflik Sosial Antar Pelajar", Jurnal Al-Misbah, Vol. 2 No.2, Juli

Prahesti Khasanah, 2014, "Meningkatkan Kemampuan Manajemen Konflik melalui Konseling Kelompok", Psikoprdia, Vol. 3 No. 2,

Tamsil Muis, dkk, 2011,"Bentuk Penyebab dan dampak dari Tindakan Kekerasan Guru terhadap Siswa dalam Interaksi Belajar Mengajar dari Perspektif Siswa di Kota Surabaya", Jurnal Psikologi Teori dan Terapan, Vol. 1 No. 2, Febuari

M. Shabir U, 2015, "Kedudukan Guru Sebagai Pendidik", Auladuna, Vol. 2 No. 2, Desember

Endang Ertanti Suhesti, 2012, Bagaimana Konselor Sekolah bersikap, Pustaka Belajar, Yogyakarta,

Hamid Patilima, 2010, Metode Penelitian Kualitatif, CV. Alfabeta, Bandung,

Sugiyono, 2017, Metode Penelitian Pendidikan, CV. Alfabeta, Bandung,

M. Ali Syamsuddin Amin, 2017, "Komunikasi sebagai Penyebab dan Solusi Konflik Sosial", Jurnal Common, Vol. 1 No. 2, Desember

Nur Chasanah, 2017, "Upaya Mengatasi Keterlambatan Siswa Masuk Kelas Melalui Layanan Penguasaan Konten dengan Teknik Manajemen Waktu”, Vol. 4 No. 2, Oktober

Suryadi, dkk, 2016, "Hubungan Kemampuan Menyelesaikan Tugas-tugas Pelajaran dengan Hasil Belajar Siswa", Jurnal Education, Vol. 2 No. 2,

Nurhayati Simatupang, 2005, "Bermain sebagai Upaya Dini Menanamkan Aspek Sosial bagi Siswa Sekolah Dasar." Jurnal Pendidikan Jasmani Indonesia, Vol. 3 No. 1,

Feny Annisa Damayanti, 2013 "Studi Tentang Perilaku Membolos pada Siswa SMA Swasta di Surabaya", Jurnal BK UNESA, Vol. 3 No.1, ,

Sulastri, dkk, 2018, "Keinginan Berhenti Merokok pada Pelajar Perokok Berdasarkan Global Youth Tobacco Survey di SMK Negeri Kota Padang", Jurnal Kesehatan Andalas, Vol. 7 No. 2,

Nunu Nurfirdaus dan Nursiti Hodijah, 2018, "Studi Tentang Peran Lingkungan Sekolah dan Pembentukan Perilaku Sosial Siswa SDN 3 Cisantana", Jurnal Ilmiah Educater, Vol. 4 No. 2, Desember

Minal Ardi, 2012, "Pengaruh Pemberian Hukuman terhadap Disiplin Siswa dalam Belajar", Jurnal EKSOS, Vol. 8 No. 1, Februari

Ratna Eliyawati dan Tatik Meiyuntariningsih, 2018, "Peran Orang Tua terhadap Prestasi Belajar Anak", Jurnal Abdikarya, Vol. 1 No 2, Desember

Erwin Erlangga, dkk, 2015, "Kepemimpinan Kepala Sekolah, Kompetensi Profesional Berpengaruh terhadap Kinerja Guru BK melalui Motivasi Kerja", Jurnal Bimbingan Konseling, Vol. 4 No. 2, 
